\title{
Periphytic Actinella Lewis (Ochrophyta, Bacillariophyceae) species from an Environmental Protection Area in the Brazilian Amazon
}

Espécies perifíticas de Actinella Lewis (Ochrophyta, Bacillariophyceae) de uma Área de Proteção Ambiental na Amazônia Brasileira

Luís Gustavo de Castro Canani ${ }^{1^{*}}$, Rebecca da Silva Fraia ${ }^{2}$ and Sérgio de Melo ${ }^{1,2}$

'Programa de Pós-graduação em Recursos Aquáticos Continentais Amazônicos - PPG-RACAM, Universidade Federal do Oeste do Pará - UFOPA, Avenida Mendonça Furtado, 2946, Fátima, CEP 68040-050, Santarém, PA, Brasil

${ }^{2}$ Instituto de Ciência e Tecnologia das Águas - ICTA, Universidade Federal do Oeste do Pará UFOPA, Avenida Mendonça Furtado, 2946, Fátima, CEP 68040-050, Santarém, PA, Brasil *e-mail: lgustavocc@gmail.com

Cite as: Canani, L.G.C., Fraia, R.S., and Melo, S. Periphytic Actinella Lewis (Ochrophyta, Bacillariophyceae) species from an Environmental Protection Area in the Brazilian Amazon. Acta Limnologica Brasiliensia, 2018, vol. 30, e209.

Abstract: Aim: The aim of this study is to present the Actinella species found in periphytic samples collected from an Environmental Protection Area in Santarém (PA, Brazil), to comment on their morphology by comparing them with existing records, and to increase knowledge of the distribution of the genus in Pará State. Methods: Ten periphytic samples were collected from seven sampling stations in the Alter do Chão Environmental Protection Area (Santarém, Pará, Brazil) in October 2015 and February and July 2016. Dissolved oxygen, $\mathrm{pH}$, conductivity and water temperature were measured in the field at sites from which samples were collected in 2016. Samples were oxidized and analyzed by light microscopy. Results: The sampled water bodies presented low conductivity and an acidic $\mathrm{pH}$. We identified 12 Actinella taxa, several of which had originally been described from samples collected from the Amazon in the mid-20 ${ }^{\text {th }}$ century, mainly in the lower Tapajós River region. Actinella rionegrensis is recorded for the first time in the State of Pará, outside of its type locality (Negro River, near Manaus, AM, Brazil), and the species habitus (wisp-shaped colonies) is recorded for the first time. Conclusion: Our results indicate that the Environmental Protection Area has been effective in conserving the aquatic ecosystem, since Actinella species identified in the mid-20 $2{ }^{\text {th }}$ century are still present. Taxonomic issues for some species of this genus need clarification and revision, since overlapping diagnostic features occur among species and with species belonging to the genus Eunotia.

Keywords: diatoms; Eunotiales; periphyton; taxonomy.

Resumo: Objetivo: Este estudo tem por objetivo apresentar as espécies de Actinella encontradas em amostras perifíticas coletadas em uma Área de Proteção Ambiental em Santarém (PA, Brasil), comentar sobre sua morfologia, comparando com os registros já existentes e ampliar o conhecimento da distribuição do gênero no estado do Pará. Métodos: Dez amostras perifíticas foram coletadas em sete estaçóes amostrais na Área de Proteçấo Ambiental de Alter do Chão (Santarém, Pará, Brasil), em outubro de 2015 e fevereiro e julho de 2016. Nas coletas de 2016, foram medidos pH, oxigênio dissolvido, condutividade e temperatura da água. As amostras foram oxidadas e analisadas em microscópia óptica. Resultados: Os corpos d'água estudados apresentaram baixa condutividade e 
$\mathrm{pH}$ ácido. Foram identificados 12 táxons do gênero Actinella, vários dos quais descritos originalmente a partir de amostras colhidas em meados do século XX na Amazônia, com destaque para região do baixo rio Tapajós. Actinella rionegrensis é registrada pela primeira vez no estado do Pará e fora de sua localidade tipo (Rio Negro, próximo a Manaus, AM, Brasil), e o hábito da espécie (colônias em roseta) é registrado pela primeira vez. Conclusão: Nossos resultados indicam que a Área de Proteção Ambiental tem sido eficiente na conservação do ecossistema aquático, já que as espécies de Actinella identificadas em meados do século 20 ainda estão presentes. Questões taxonômicas precisam ser esclarecidas e revistas para algumas espécies deste gênero, pois apresentam sobreposição de características diagnósticas entre si e entre espécies do gênero Eunotia.

Palavras-chave: diatomáceas; Eunotiales; perifíton; taxonomia.

\section{Introduction}

The order Eunotiales Silva belongs to the subclass Bacillariophycidae D.G. Mann, Class Bacillariophyceae Haeckel, sensu Ruggiero et al. (2015). They are the only group of diatoms whose valves have both a raphe system and rimoportulae. There is no central nodule, the raphe is placed distally and reduced, and in most genera it is mainly located in the mantle (Round et al., 1990; Siver et al., 2015). To date, 12 genera have been proposed (more recently Perinotia Metzeltin \& Lange-Bertalot, Bicudoa Wetzel et al., Eunotioforma Kociolek \& Burliga, and Actinellopsis Taylor et al.), some of which are not widely recognized (Siver et al., 2015).

Among the Eunotiales, Actinella Lewis is the second largest genus after Eunotia Ehrenberg, comprising about 60 to 100 species (Melo et al., 2010; Ripple and Kociolek, 2013; Siver et al., 2015). Both of these genera present asymmetric valves with respect to the apical axis, and their main distinguishing feature is the valve heteropolarity of Actinella and the isopolarity of Eunotia. However, differentiating species among genera is not always straightforward, especially in cases where the valve heteropolarity is subtle (e.g. Actinella rionegrensis Metzeltin \& Lange-Bertalot) or facultative in a population (e.g. Eunotia rhomboidea Hustedt, E. faba Ehrenberg, E. ibitipocaensis Canani \& Torgan, E. papilioforma Furey, Lowe \& Johansen), or for heteropolar taxa presenting a "eunotioid" valve outline (e.g. A. pseudohantzschia Metzeltin \& Lange-Bertalot, $A$. sabbei Metzeltin \& Lange-Bertalot). These potentially distinguishing characteristics, as well as the uncertainty regarding affiliations and indeed recognition of newly proposed taxa, have been debated in several studies (Metzeltin \& Lange-Bertalot, 1998, 2007; Kociolek et al., 2001; Sabbe et al., 2001; Canani \& Torgan, 2013; Siver et al., 2015).

Actinella occurs on all continents (Tremarin et al., 2016), but the main centers of diversity are in the southern hemisphere, including tropical South
America, Africa and Australasia (Metzeltin \& Lange-Bertalot 1998, 2007; Sabbe et al., 2001). Grunow in Van Heurck (1881) recorded the first three species of Actinella for Brazil, but only presented illustrations without descriptions-A. guianensis Grunow, A. brasiliensis Grunow and A. mirabilis Grunow-all from Amazonian environments. In the mid-twentieth century, Hustedt (1952) described A. eunotioides Hustedt, $A$. peronioides Hustedt and $A$. robusta Hustedt, and later, $A$. gessner $i$ Hustedt and A. siolii Hustedt from samples collected at Jurucuí Lake and the Arapiuns River in the municipality of Santarém (Hustedt, 1965). Thereafter, the genus was reported from Amazonian rivers and lakes based on several studies examining taxonomy and/or structure of phytoplankton (Uherkovich \& Rai, 1979; Uherkovich, 1981; Melo et al., 2004, 2005) or periphytic algal assemblages (Uherkovich \& Franken, 1980; Putz, 1997); the taxonomy, composition and variation of phytoplanktonic or periphytic diatom assemblages (Diaz-Castro et al., 2003; Ferrari et al., 2007; Raupp et al., 2009); and the stomach contents of aquatic animals (Souza-Mosimann et al., 1997; Alencar et al., 2001).

To date, only two studies have focused solely on the genus Actinella from Amazonian environments. A review by Kociolek et al. (2001) of South American species revisited Hustedt's collection and proposed seven new species from among 16 taxa. All of those taxa had been present in samples collected from the Santarém region in the past (except for A. lima Kociolek, which was recorded later in Jurucuí Lake from among Hustedt's collection by Metzeltin \& Lange-Bertalot, 2007). The authors of that review highlighted the Amazon Basin as being an important center of diversity for the genus, but incorrectly stated that Actinella is restricted to this area and is absent from non-tropical regions of Brazil. Melo et al. (2010) recorded five species of Actinella from planktonic samples collected in a 'blackwater' lake in the Central Amazon and summarized records of Actinella from the Brazilian Amazon region, amounting to a total of 25 taxa, 
19 of which were recorded in Pará State, mostly collected from the lower Tapajós River area.

Metzeltin \& Lange-Bertalot (1998, 2007) described 377 new diatom taxa from tropical environments, mostly from samples collected in Colombia, Venezuela, Guyana, and Brazil. In those studies, the authors drew attention to the diversity of the Tapajós River aquatic system, particularly Jurucuí Lake that is the type locality for several new species of Actinella proposed by Metzeltin \& Lange-Bertalot $(1998,2007)$ and Kociolek et al. (2001). They also pointed out the considerable species richness of the Order Eunotiales, totaling 194 and 24 species of the genera Eunotia and Actinella, respectively (16 of these latter were proposed as new species).

Almost 70 years have passed since the collections of Rudolf Braun and Harald Sioli (Braun, 1952; Sioli \& Soares, 2006) from the Santarém region (PA, Brazil), samples from which were used to describe most of the known South American Actinella species. We collected periphytic samples from the lower Tapajós River region as part of an investigation of the periphytic diatoms in the Environmental Protection Area of Alter-do-Chão (APA Alter do Chão, Santarém, PA, Brazil). We aimed to extend our knowledge of tropical South American Actinella species by updating and expanding records for the State of Pará. Here, we describe and illustrate the taxa, we comment on their morphologies and habitus, and we address some taxonomic issues.

\section{Material and Methods}

Study Area - The Environmental Protection Area of Alter do Chão (APA Alter do Chão) was created in 2003. It covers an area of 16,180 ha and is located approximately $35 \mathrm{~km}$ from the city of Santarém, in Pará State, Brazil. The protected area includes several streams ('igarapés') and floodplain lakes connected to the Tapajós River (a 'clearwater river' according to Sioli's Amazonian river typology, Sioli, 1984), including the lakes Verde and Jurucuí. Verde Lake has a surface area of approximately 445 ha and is situated at the right bank of the Tapajós River (Figure 1).

Sampling and analysis - The 10 periphytic samples used in this study were collected from seven sampling stations in October 2015 and February and July 2016 (Table 1). We collected leaves, petioles, stems or whole submerged macrophytes (in the case of small plants), submerged tree bark, and superficial sediments from the littoral zone of Verde Lake and the banks and beds of its associated streams. To collect surface sediments, we gently pushed an inverted Petri-dish against the submerged surface and slid a rigid plastic square underneath it. Samples were stored in bottles or Ziploc ${ }^{\circledR}$ plastic



Figure 1. Maps of the study area showing the locations of the sampling stations (a), in the lower Tapajós River region (b) of Pará State (c). 
Table 1. Data on water parameters for sampling stations (SS). HSTM: deposit number in the HSTM-Algas herbarium; DO: dissolved oxygen $\left(\mathrm{mg} \mathrm{L}^{-1}\right)$; EC: electrical conductivity $\left(\mu \mathrm{cm}^{-1}\right)$; T: water temperature $\left({ }^{\circ} \mathrm{C}\right)$.

\begin{tabular}{|c|c|c|c|c|c|c|c|c|}
\hline SS & HSTM & Coordinates & Sampling date & Substratum & DO & EC & $\mathrm{pH}$ & $T$ \\
\hline APA05 & 9485 & $\begin{array}{l}02^{\circ} 29^{\prime} 03.4^{\prime \prime} \mathrm{S} \\
54^{\circ} 56^{\prime} 09.8^{\prime \prime} \mathrm{W}\end{array}$ & $01 / 10 / 2015$ & macrophyte & - & - & - & - \\
\hline APA08 & 9489 & $02^{\circ} 28^{\prime} 57.3^{\prime \prime} \mathrm{S}$ & 01/10/2015 & $\begin{array}{l}\text { submerged } \\
\text { woody stem }\end{array}$ & - & - & - & - \\
\hline APA09 & $\begin{array}{l}9490 \\
9514\end{array}$ & $\begin{array}{l}54^{\circ} 56^{\prime} 31.0^{\prime \prime} \mathrm{W} \\
02^{\circ} 28^{\prime} 59.2^{\prime \prime} \mathrm{S} \\
54^{\circ} 57^{\prime} 04.4^{\prime \prime} \mathrm{W}\end{array}$ & $12 / 02 / 2016$ & $\begin{array}{l}\text { Sediment } \\
\text { submerged } \\
\text { woody stem }\end{array}$ & 8.1 & 8.5 & 5.8 & 29.7 \\
\hline APA03 & $\begin{array}{l}9521 \\
9522\end{array}$ & $\begin{array}{l}02^{\circ} 30^{\prime} 59.2^{\prime \prime} \mathrm{S} \\
54^{\circ} 56^{\prime} 53.1^{\prime \prime} \mathrm{W}\end{array}$ & $14 / 07 / 2016$ & $\begin{array}{l}\text { macrophyte } \\
\text { macrophyte }\end{array}$ & 2.8 & 9.6 & 6.1 & 29.8 \\
\hline APA16 & 9535 & $\begin{array}{l}02^{\circ} 28^{\prime} 26.0^{\prime \prime} \mathrm{S} \\
54^{\circ} 54^{\prime} 34.2^{\prime \prime} \mathrm{W}\end{array}$ & 18/07/2016 & macrophyte & 1.5 & 7.8 & 4.9 & 28.6 \\
\hline APA12 & $\begin{array}{l}9537 \\
9538\end{array}$ & $\begin{array}{l}02^{\circ} 29^{\prime} 03.2^{\prime \prime} \mathrm{S} \\
54^{\circ} 54^{\prime} 28.7^{\prime \prime} \mathrm{W}\end{array}$ & 18/07/2016 & $\begin{array}{l}\text { macrophyte } \\
\text { macrophyte }\end{array}$ & 1.7 & 8.8 & 4.8 & 28.2 \\
\hline APA23' & 9552 & $\begin{array}{l}02^{\circ} 32^{\prime} 58.9^{\prime \prime} \mathrm{S} \\
54^{\circ} 57^{\prime} 12.0^{\prime \prime} \mathrm{W}\end{array}$ & 22/07/2016 & macrophyte & 1.3 & 15.0 & 4.8 & 25.9 \\
\hline
\end{tabular}

bags. In the laboratory, samples were conditioned in flasks and fixed with $4 \%$ formaldehyde solution. During the February and July 2016 sampling campaigns, we measured in situ $\mathrm{pH}$ ( $\mathrm{pH}$ system model 60, YSI, Ohio, USA), water temperature and dissolved oxygen (oximeter model 55, YSI, Ohio, USA), and electrical conductivity (Ecosense model EC 300A conductivity/temperature, YSI, Ohio, USA). To equalize sample sizes for oxidation, portions of macrophytes were cut into small pieces and placed in a graduated test tube up to the mark of $3 \mathrm{ml}\left(3 \mathrm{~cm}^{3}\right)$ (modified from Lim et al., 2001). The same volume was used for sediment samples. Samples of the periphyton were extracted by brush scraping (for macrophytes) or by shaking in distilled water (both macrophytes and sediment). Aliquots of $2 \mathrm{ml}$ were oxidized according to Von Stosch (1970). Permanent slides were made in duplicate using $\operatorname{Naphrax}^{\circledR}($ R.I. $=1.74)$ as a mounting medium.

The slides were observed under a Zeiss Axio Scope A1 light microscope (LM) with a 100x oil immersion objective at a magnification of $1000 x$. Specimens were photographed and measured using the ZEN 2012 (blue edition) software and image capture system. The widths were measured at the midsection of the valves.

We adopted the classification for higher taxonomic levels (from phylum to order) proposed by Ruggiero et al. (2015), and identifications to specific and infra-specific level were based on several studies of flora and both classic and recent publications (van Heurck, 1881; Hustedt, 1952, 1965; Metzeltin \& Lange-Bertalot, 1998, 2007; Kociolek et al., 2001; Ferrari et al., 2007;
Melo et al., 2010). Samples are currently housed in the HSTM-Algas herbarium at the Federal University of Western Pará (UFOPA).

\section{Results and Discussion}

The low values of electrical conductivity and the acidic $\mathrm{pH}$ we recorded from our water samples indicate oligotrophic water conditions in the lower Tapajós region (Table 1), which are suitable for Actinella and for the Order Eunotiales in general (Round et al., 1990; Montoya-Moreno \& Aguirre-Ramirez, 2013).

The genus Actinella was represented by 12 infrageneric taxa, which we identified based on their morphometry. Numbers of individuals analyzed (n) for each species is presented.

\section{Phylum Ochrophyta Cavalier-Smith \\ Class Bacillariophyceae Haekel \\ Subclass Bacillariophycidae D.G. Mann \\ Order Eunotiales P.C. Silva \\ Family Eunotiaceae Kützing \\ Genus Actinella F.W. Lewis}

Actinella brasiliensis Grunow in Van Heurck

Description: Valves heteropolar, slightly arcuate, margins parallel. Headpole broadly rounded, with median apical projection, which is progressively displaced to the dorsal side as the valvar length increases; footpole narrowly rounded. Length: 40.8-92.1 $\mu \mathrm{m}$; width: 4.3-7.2 $\mu \mathrm{m}$; striae parallel, $14-18$ in $10 \mu \mathrm{m}$ (Figure 2a-c). 


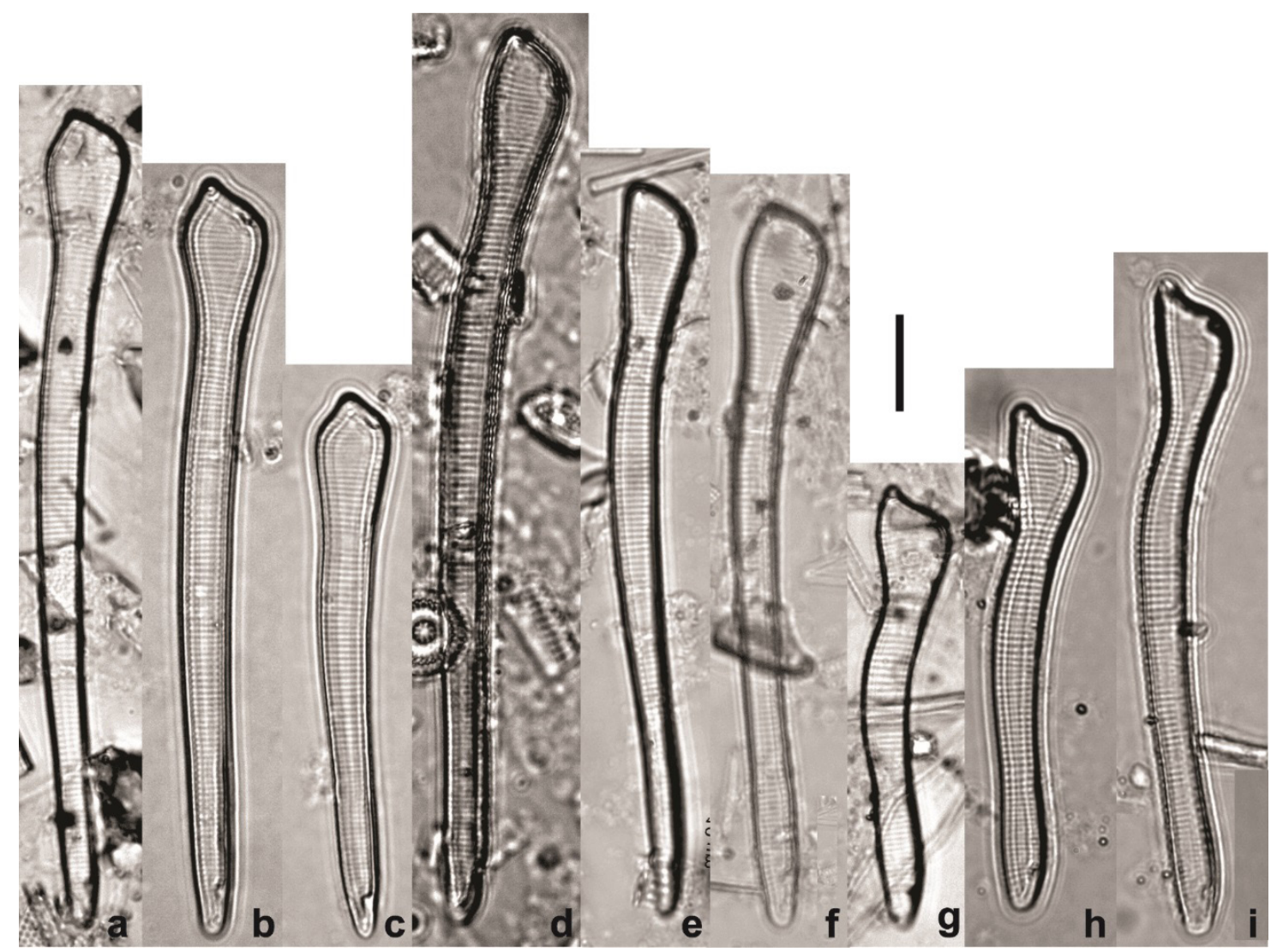

Figures 2a-i. General view of Actinella spp. valves under LM. 2a-c. A. brasiliensis. 2d-f. A. crawfordii. 2g-i. A. curvatula (scale bar: $10 \mu \mathrm{m}$ ).

Studied material $(\mathrm{n}=20)$ : HSTM-Algas 9489, 9521, 9522, 9535, 9552.

Comments: Grunow in Van Heurck (1881) presented two specimens (Fig. 35: 19) that are morphometrically different. Metzeltin \& Lange-Bertalot (2007) selected as the lectotype the individual to the right, corresponding to A. brasiliensis sensu Hustedt in Schmidt et al. (Fig. 292: 10, 11, 19, from Guyanese samples) and sensu Kociolek et al. (2001). The individuals presented in this study were identified based on the characteristics of the lectotype.

Actinella crawfordii Kociolek

Description: Valves heteropolar, slightly arched; margins parallel, spines on the valve margins barely visible under LM (Fig 2d). Headpole inflated, with barely protruding apical projection, continuous with the dorsal margin; footpole narrowly rounded. Length: 75.7-155.7 $\mu \mathrm{m}$; width: 3.9-5.7 $\mu \mathrm{m}$; striae parallel, 13-16 in $10 \mu \mathrm{m}$ (Figure 2d-f).

Studied material $(\mathrm{n}=6)$ : HSTM-Algas 9489, 9490, 9521, 9522.

Comments: In the protologue, Kociolek et al. (2001) noted $12-14$ striae in $10 \mu \mathrm{m}$, but the individuals depicted in Figs. 119 and 120 of that review exhibit $15-16$ striae in $10 \mu \mathrm{m}$ at the midsection of the valve, which is in accordance with the specimens we observed in the present study. The individuals illustrated by Metzeltin \& Lange-Bertalot (1998, Figure 6: 1-5), which were subsequently identified as $A$. crawfordii by Metzeltin \& Lange-Bertalot (2007, Figure 6: 1-4), have very prominent apical projections (as noted by those authors) and present a more convex apical pole margin, which in our opinion render those specimens more similar to $A$. curvatula Kociolek.

\section{Actinella curvatula Kociolek}

Description: Valves heteropolar, dorsal margin strongly convex near the headpole, particularly for smaller specimens. Headpole inflated, with concave margin and pronounced apical projection, continuous with the dorsal margin; footpole slightly detached and narrowly rounded. Length: 46.6-96.8 $\mu \mathrm{m}$; width: 4.5-5.5 $\mu \mathrm{m}$; striae parallel, $14-17$ in $10 \mu \mathrm{m}$ (Figure $2 \mathrm{~g}-\mathrm{i}$ ).

Studied material $(\mathrm{n}=15)$ : HSTM-Algas 9490, 9522, 9521, 9522, 9535, 9537, 9538, 9552.

Comments: Measurements of our specimens are concordant with those presented in the protologue. 
In the identification key provided by Kociolek et al. (2001), the distinctive feature of this taxon is its concave headpole margin, although this was not mentioned in the original description of the species. We consider this feature, as well as the taxon's strong dorsal convexity, as differentiating it from other similar taxa, such as $A$. crawfordii and $A$. lima.

\section{Actinella gracilis Kociolek}

Description: Valves heteropolar, slightly arched, margins parallel. Headpole slightly dilated, with apical projection continuous with the dorsal margin; footpole narrowly rounded. Length: 68.9-122.6 $\mu \mathrm{m}$; width: 3.3-4.1 $\mu \mathrm{m}$; striae parallel, 16-18 in $10 \mu \mathrm{m}$ (Figure 3a-c).

Studied material $(\mathrm{n}=5)$ : HSTM-Algas 9485, 9489, 9521, 9522.

Comments: The striae density is not given in the original description. Metzeltin \& LangeBertalot (2007) noted a probable mistake in the scale presented in the protologue illustrations (Kociolek et al., 2001). Considering the scale given with Fig. 113, the specimen is approximately $2.3 \mu \mathrm{m}$ wide and presents around 25 striae in $10 \mu \mathrm{m}$, whereas specimens shown in Figs. 114 and 116 could be estimated as having 16 and 18 striae in $10 \mu \mathrm{m}$, respectively. These latter numbers are consistent with the specimens identified in our study, as well as with those recorded by Melo et al. (2010), supporting that there is indeed a mistake with respect to the scale bar provided with the specimen shown in Fig. 113. Therefore, we consider the striae density for $A$. gracilis to be in the range of 16-18 in $10 \mu \mathrm{m}$.

Actinella guianensis Grunow in Cleve

Description: Valves heteropolar, arched, margins parallel with conspicuous spines. Headpole rounded, strongly dilated, with median apical projection slightly displaced to the dorsal margin; footpole inflated with rounded apex. Length: $85.8-165.6 \mu \mathrm{m}$; width: $5.6-8.2 \mu \mathrm{m}$; striae parallel, $12-15$ in $10 \mu \mathrm{m}$ (Figure 3d-f).

Studied material $(\mathrm{n}=10)$ : HSTM-Algas 9485, 9489, 9490, 9514, 9521, 9522.

Comments: Measurements, striae density and shape of our specimens are concordant with those presented in the protologue (Van Heurck, 1881) and in Metzeltin \& Lange Bertalot (1998), Kociolek et al. (2001) and

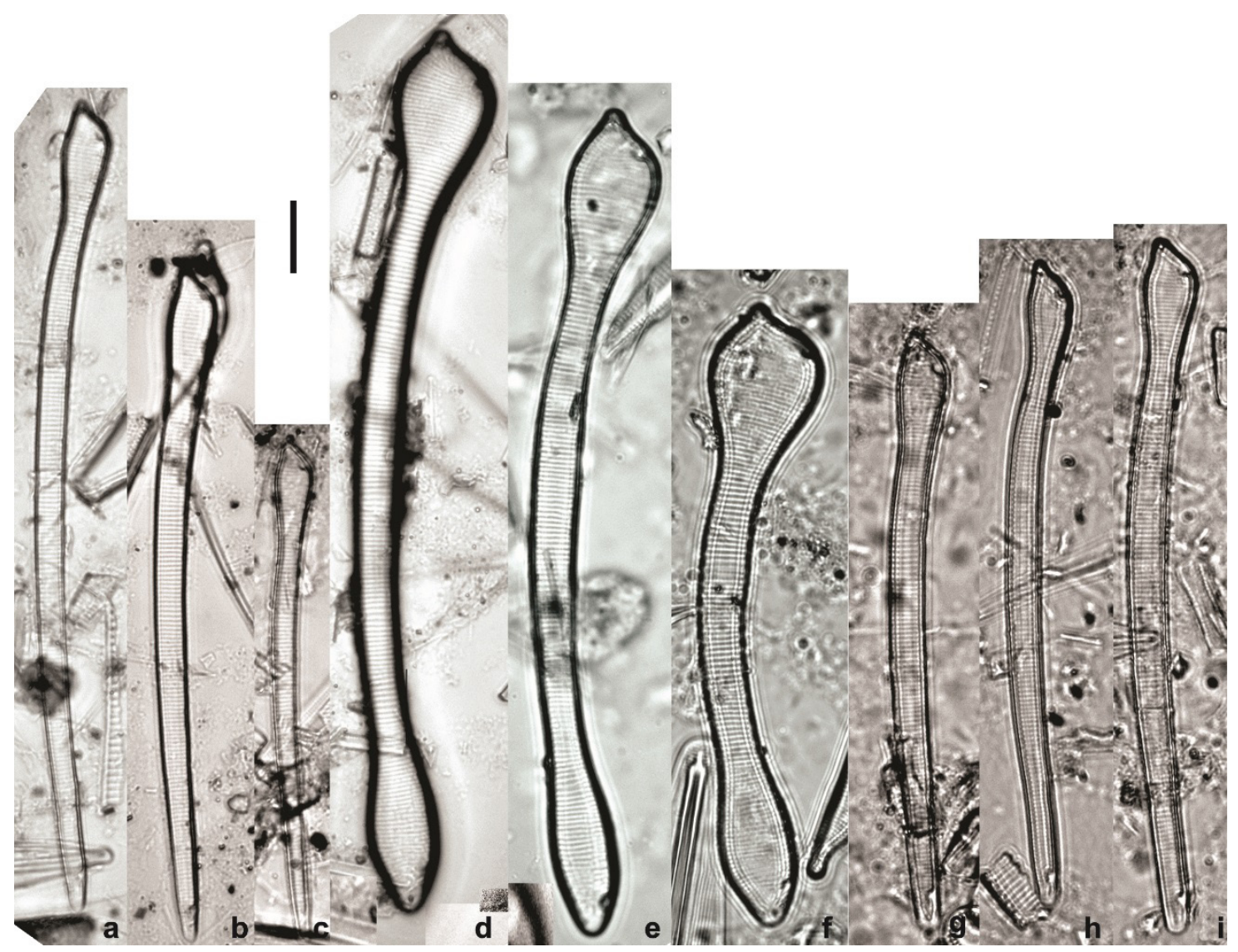

Figures 3a-i. General view of Actinella spp. valves under LM. 3a-c. A. gracilis. 3d-f. A. guianensis. 3g-i. A. lima (scale bar: $10 \mu \mathrm{m})$. 
Melo et al. (2010), all of them from Amazonian samples. Bicca et al. (2011, Figs. 2 and 3) and Dunk et al. (2016, Figs. 2d-f) present specimens of A. guianensis with non-apiculate, less dilated headpoles, from samples collected outside the Amazon (Southern and Central Brazil, respectively). Additionally, the headpole and the footpole of those specimens are almost of the same width, unlike those from Amazonian samples. Further investigation is needed to determine whether they are morphotypes or distinct species.

\section{Actinella lima Kociolek}

Description: Valves heteropolar, slightly arched, margins parallel. Headpole slightly inflated, rounded, with apical projection displaced to the dorsal side; footpole rounded. Length: 81.3-153.9 $\mu \mathrm{m}$; width: 4.5-5.9 $\mu \mathrm{m}$; striae parallel, $15-18$ in $10 \mu \mathrm{m}$ (Figure 3g-i).

Studied material $(\mathrm{n}=8)$ : HSTM-Algas 9485, 9489, 9521, 9522.

Comments: The analyzed specimens have a more pronounced apical projection than those illustrated by Kociolek et al. (2001), in which this structure hardly projects beyond the valve body and is more rounded. However, the morphology of our specimens agrees with the specimens illustrated by Metzeltin \& Lange-Bertalot (2007) (Figure 28: 3-8). This taxon is quite similar to $A$. gracilis, mainly in relation to the valve outline and the headpole shape, but it differs from it by the valvar width being $\geq 4$ $\mu \mathrm{m}$ (Kociolek et al., 2001), which is the principle feature we used to distinguish these two taxa.

Actinella pseudohantzschia Metzeltin \& Lange-Bertalot

Description: Valves dorsiventral, with discrete heteropolarity, slightly concave ventral margin and convex dorsal margin. Headpole and footpole little differentiated, subcapitate to rostrate. Length: 56.2-65.3 $\mu \mathrm{m}$; width: 7.5-7.9 $\mu \mathrm{m}$; 9-10 conspicuously punctate striae in $10 \mu \mathrm{m}$, parallel to radiate at the poles, which can be interrupted. Phantom striae are present in the ventral margin (Figure 4a-b).

Studied material $(\mathrm{n}=2)$ : HSTM-Algas 9485.

Comments: Actinella pseudohantzschia is related to $A$. eunotioides Hustedt, but differs from it by the pattern of the striae, its slightly larger width, and the presence of conspicuous spines (even under LM) at the valvar margins. In the protologue, Hustedt (1952: 135) observed the presence of spines (7-10 in $10 \mu \mathrm{m})$ in A. eunotioides. However, when comparing these two species, Metzeltin \& Lange-Bertalot (2007) stated that spines were

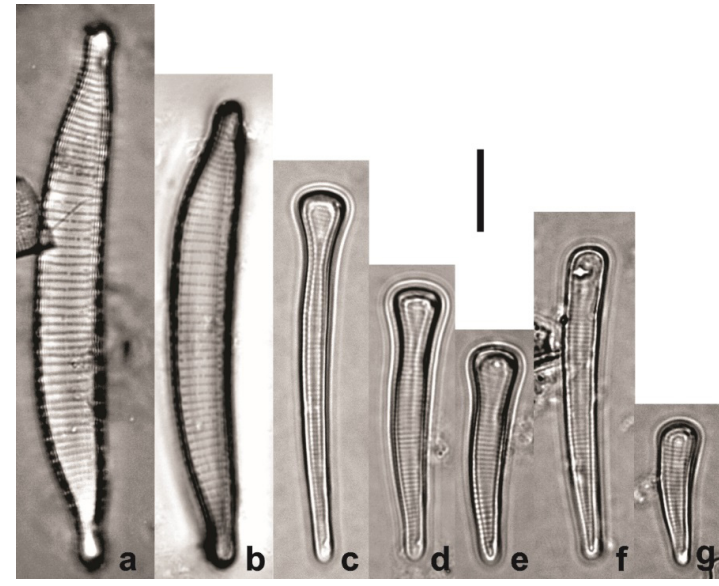

Figure 4a-g. General view of Actinella spp. valves under LM. 4a-b. A. pseudohantzschia. 4c-e. A. peronioides. 4f-g. $A$. aff. subperonioides (scale bar: $10 \mu \mathrm{m}$ ).

absent from the samples collected in Guyana and Brazil (including the type material), and provided details of length, width and striae density that do not match those provided in the protologue for A. eunotioides. In an amendment of Hustedt's original description, Kociolek et al. (2001) report the presence of spines in the margins, but in their commentary of observations by scanning electron microscopy, they say that they are absent.

Eunotia roland-schmidtii Metzeltin and LangeBertalot is also similar to Actinella pseudohantzschia, but is longer, and its width and striae number overlap with those of $A$. eunotioides. Individuals with or without conspicuous spines have been illustrated (Metzeltin \& Lange-Bertalot, 2007: 457). The authors of that report expressed uncertainty regarding whether E. roland-schmidtii belonged to the genus Eunotia or to Actinella, since longer specimens of Actinella tend to be isopolar and several Actinella species lack spines. Actinella disjuncta Metzeltin and Lange-Bertalot is another species similar to $A$. pseudohantzschia, but it generally is shorter and exhibits greater striae density.

Apart from the individuals we illustrate here (whose characteristics match the description of A. pseudohantzschia), we found specimens from several samples that simultaneously present morphometric characteristics of $A$. pseudohantzschia, A. eunotioides and E. roland-schmidtii. In general we found that the larger the specimen the harder it was to assign species identity to it due to progressively subtle heteropolarity and overlapping morphometric features. We propose that more detailed ultrastructural analyses of populations are needed to establish distinct species boundaries, 
to differentiate lifecycle stages, and to reveal intraspecific morphological variation.

Actinella peronioides Hustedt

Description: Valves heteropolar, clavate, slightly arched, margins straight. Headpole capitate-truncate, apical projection absent; footpole narrowly rounded. Length: $18.5-45.3 \mu \mathrm{m}$; width: 4.7-6.1 $\mu \mathrm{m}$ (headpole) and 2.2-2.9 (footpole); striae parallel to radiate, 17-20 in $10 \mu \mathrm{m}$ (Figure 4c-e).

Studied material $(\mathrm{n}=8)$ : HSTM-Algas 9535, 9537, 9538.

Comments: Morphometric characteristics of the specimens we examined are in agreement with those presented for the species (Hustedt, 1952; Kociolek et al., 2001). Metzeltin \& Lange-Bertalot (2007) reported that they observed large morphological heterogeneity in the samples of Hustedt's collection from Brazil, stating that the morphological groups they delineated may constitute distinct species or subspecies. In that same work, the authors proposed two new species related to $A$. peronioides, i.e. $A$. superperonioides Metzeltin \& Lange-Bertalot (from the same sampling location as the $A$. peronioides type material) and $A$. subperonioides Metzeltin \& Lange-Bertalot (representing samples from Venezuela, i.e. not the type locality of $A$. peronioides). Compared to $A$. peronioides, $A$. superperonioides presents a larger valve length (about $100 \mu \mathrm{m}$ compared to $<75 \mu \mathrm{m}$ for $A$. peronioides), a larger footpole (3.5-5.0 $\mu \mathrm{m}$ compared to $<2.3 \mu \mathrm{m}$ for $A$. peronioides), a larger mid-valve width (4.0-5.0 $\mu \mathrm{m}$, compared to $<3.5 \mu \mathrm{m}$ for $A$. peronioides), more arched valves, subcapitate apices and lower striae density, as well as less capitate headpoles. A. subperonioides (see Figures 4f-g) differs from $A$. peronioides by having narrower rather than capitate headpoles. Some related morphological groups remained undetermined (Figure 46: 18-32 in Metzeltin \& Lange-Bertalot, 2007).

Observations of non-oxidized samples revealed pairs of individuals adhered to the substratum through a branched (bifurcated) mucilaginous stalk (Figure $5 \mathrm{~b}$ ), as reported for $A$. aoteoaroaia Lowe et al., illustrated in Sabbe et al. (2001). This latter taxon also exhibits a very similar girdle outline compared to $A$. peronioides.

Actinella aff. subperonioides Metzeltin \& Lange-Bertalot

Description: Valves heteropolar, clavate, slightly arched, margins parallel. Headpole slightly rounded, not capitate, without apical projection; footpole narrowly rounded. Length: 17.6-38.1 $\mu \mathrm{m}$;

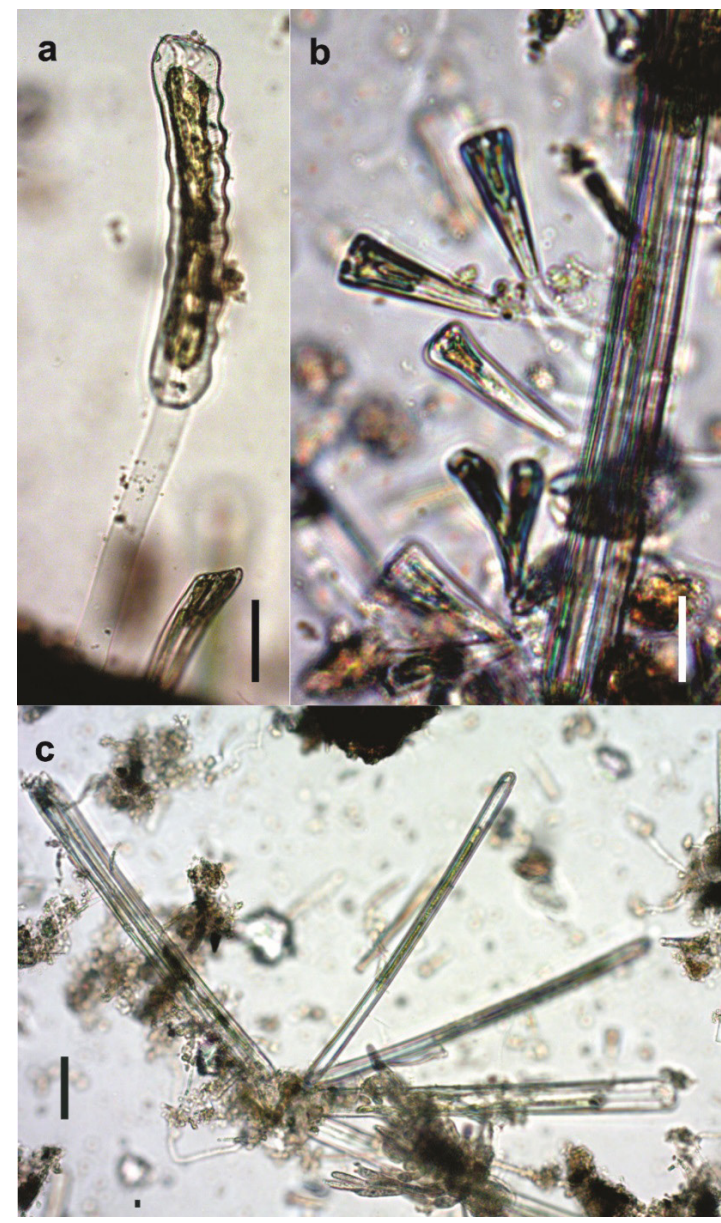

Figure 5a-c. Habitus of some Actinella species, as observed under LM. 5a. Thick stalk of $A$. mirabilis. 5b. Branched stalk of $A$. peronioides. 5c. Rosette colony of A. rionegrensis. (scale bars: $5 \mathrm{a}: 50 \mu \mathrm{m} ; 5 \mathrm{~b}$ and 5c: $20 \mu \mathrm{m}$ ).

width: 4.6-5.2 $\mu \mathrm{m}$ (headpole) and 2.1-2.5 (footpole); striae parallel, 19-21 in $10 \mu \mathrm{m}$ (Figure 4f-g).

Studied material $(\mathrm{n}=4)$ : HSTM-Algas 9535, 9537, 9538.

Comments: As they did for the species group related to $A$. eunotioides, Metzeltin \& Lange-Bertalot (2007) proposed the separation of $A$. peronioides into at least two more species (A. subperonioides and $A$. superperonioides, with some indeterminate morphotypes). Some individuals that we analyzed possess a valve contour that is very similar to the undetermined specimens shown in Metzeltin \& Lange-Bertalot (2007, Figure 46: 24-32), which are between 12.3-41.5 $\mu \mathrm{m}$ in length, 3.8-4.6 $\mu \mathrm{m}$ (headpole) and 3.1-3.8 $\mu \mathrm{m}$ (footpole) in width, and have $18-19$ striae in $10 \mu \mathrm{m}$. Relative to the new species proposed by Metzeltin \& Lange-Bertalot (2007), our specimens more resemble A. subperonioides (Metzeltin \& Lange-Bertalot, 2007, Figure 46: 1-10), but have a greater striae density, 
which is why we designate them $A$. aff. subperonioides. With respect to the $A$. peronioides species complex, again there are problems concerning overlapping measurements and the existence of a morphological continuum among specimens. This makes it difficult to assign specimens to species, as discussed above for the $A$. eunotioides species complex. Thus, it remains unclear if $A$. peronioides should be differentiated into more than one species.

\section{Actinella mirabilis Grunow in Van Heurck}

Description: Valves slightly heteropolar, arched, with parallel undulating margins. Both headpole and footpole broadly inflated, with cuneate apexes. Length: 276.6-371.3 $\mu \mathrm{m}$; width: 19.6-25.1 $\mu \mathrm{m}$; striae parallel to irregular, $10-12$ in $10 \mu \mathrm{m}$, which are disjointed near the ventral margin and form a longitudinal line (Figure 6a).

Studied material ( $\mathrm{n}=2)$ : HSTM-Algas 9535.

Comments: This species presents a unique undulating pattern on both margins, so it can hardly be confused with any other currently described taxon. Metzeltin \& Lange-Bertalot (1998: 242) proposed a 'natural constant' concerning the number of undulations on the margins of A. mirabilis,

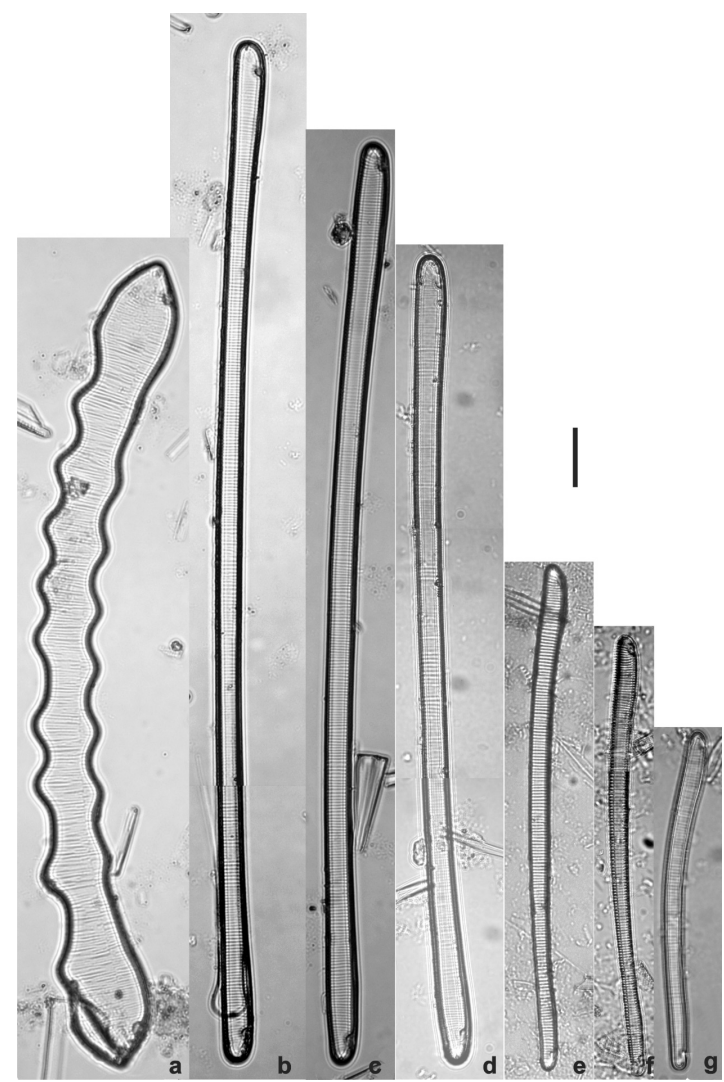

Figure 6a-g. General view of Actinella spp. valves under LM. 6a. A. mirabilis. 6b-d. A. rionegrensis. 6e-g. A. robusta (scale bar: $20 \mu \mathrm{m}$ ). i.e. that the number of undulations on the dorsal side is always two more than that on the ventral side. Our analysis supports this claim, since the specimen shown in Figure 6a exhibits nine undulations on the dorsal margin and seven on the ventral margin. Observations of non-oxidized epiphytic samples revealed solitary individuals adhered to the substratum by a thick mucilaginous stalk (Figure 5a), confirming the sessile habitus of this taxon, as noted by Uherkovich (1986) in Kociolek et al. (2001).

Actinella rionegrensis Metzeltin \& Lange-Bertalot

Description: Valves isopolar, slightly arched, margins parallel. Both headpole and footpole rounded. Length: 254.1-350.3 $\mu \mathrm{m}$; width: 8.3-9.0 $\mu \mathrm{m}$ (center), 10.1-10.8 $\mu \mathrm{m}$ (headpole), 10.1-10.4 $\mu \mathrm{m}$ (footpole); striae parallel, 9-12 in $10 \mu \mathrm{m}$ (Figure 6b-d).

Studied material $(\mathrm{n}=6)$ : HSTM-Algas 9535, 9537, 9538.

Comments: Whether this isopolar taxon should be included in the genus Actinella is another example of the difficulty of establishing and applying morphological criteria that can clearly separate the genera Eunotia and Actinella. Observations of non-oxidized samples revealed several frustules joined at their footpoles (forming rosette colonies, sensu Rimet \& Bouchez, 2012) that were adhered to the substratum (Figure $5 \mathrm{c}$ ). Adherence to the substrate at one of the poles is common among species of Actinella, whereas this is rare in the genus Eunotia. We present the first record for this taxon outside its type locality and for Pará State, as well as the first description of its colony morphology.

Actinella robusta Hustedt

Description: Valves heteropolar, slightly arched, margins parallel. Headpole obliquely rounded; footpole rounded. Length: 116.1-173.6 $\mu \mathrm{m}$; width: 5.7-7.4 $\mu \mathrm{m}$ (center), 6.5-8.6 $\mu \mathrm{m}$ (headpole), 5.3-5.6 $\mu \mathrm{m}$ (footpole); striae parallel, $10-11$ in $10 \mu \mathrm{m}$ (Figure 6e-g).

Studied material $(\mathrm{n}=3)$ : HSTM-Algas 9485, 9489, 9535.

Comments: Valve length reaches $400.0 \mu \mathrm{m}$ in the protologue for $A$. robusta. We did not find records of such long specimens in other studies; maximum valve length is about $184.0 \mu \mathrm{m}$ in Kociolek et al. (2001, p.139, Figs 36-39), $216.0 \mu \mathrm{m}$ in Melo et al. (2010), and $173.6 \mu \mathrm{m}$ in this study.

\section{Conclusion}

Our investigation of Actinella species from the lower Tapajós River region revealed that this flora has not changed very much since collections 
made in the mid- $20^{\text {th }}$ century, indicating that the Environmental Protection Area is effective in terms of conserving the aquatic ecosystem. The only species we found that had not previously been reported for this region was Actinella rionegrensis, which was initially described from samples collected in the Negro River, a 'blackwater' river (according to Sioli, 1984) and one of the most important tributaries of the Amazon River. However, if the taxonomic distinctiveness of $A$. subperonioides is confirmed, it will be the first record of this taxon in Brazil (and outside its type locality of Venezuela).

We found 12 of the 25 taxa presented in the study carried out by Melo et al. (2010), who summarized the occurrence of Actinella in the Brazilian Amazon. It is notable that from only 10 samples analyzed in this study, we encountered about $50 \%$ of the Actinella diversity reported in previous studies for this region, including those by Metzeltin \& Lange-Bertalot (1998, 2007), wherein about 500 slides from tropical South American samples were investigated.

We did not find the 13 species that have previously been reported for the Brazilian Amazon. Of these, we believe that neither $A$. punctata (that is the typus generis) nor $A$. tasmaniensis occur in the Brazilian Amazon, even though both of these taxa were reported in the study by Uherkovich $\&$ Franken (1980), but the authors did not provide any illustrations. That study represents the only report for $A$. tasmaniensis outside Australasia (Williams \& Kociolek, 2016). We believe that the specimens identified as $A$. tasmaniensis and as A. punctata by Uherkovich \& Franken (1980) were probably confused with other similar species, as is likely the case for reports of $A$. punctata in other countries (Kociolek et al., 1997). Actinella punctata is commonly found in the northern regions of the Holarctic and has only been reported in South America from a lake in Colombia c. $3000 \mathrm{~m}$ above sea level (Metzeltin \& Lange-Bertalot, 2007). Alencar et al. (2001, Fig. 33) also reported A. punctata from the Brazilian Amazon, but their illustrated specimen is actually $A$. siolii. The remaining species not registered in this study but that have been previously reported for the Brazilian Amazon are also rarely recorded in other studies or have only been found once at their type localities.

The gradient of morphological characters found among some taxa, together with overlapping character measurements, makes assigning taxonomy for some specimens difficult, as has been found for the $A$. brasiliensis species complex (comprising A. brasiliensis, A. hustedtii Kociolek, A. spauldingae Metzeltin \& Lange-Bertalot, A. curvatula, A. lima, $A$. crawfordii and $A$. gracile) and the $A$. peronioides species complex (comprising $A$. peronioides, A. subperonioides and $A$. superperonioides). It is even difficult to assign certain taxa to either the Actinella or Eunotia genera, as is the case for A. pseudohantzschia, A. lange-bertalotti Kociolek, $A$. eunotioides and $E$. roland-schmidt. Thus, a more detailed revision of this group is necessary, using morphological, ultrastructural, molecular, and biogeographical data. Observations of species forms throughout their lifecycle and their habitus in fresh samples may help. Actinella commonly attaches itself to the substrate through mucilage pads or stalks that grow from the footpole. This genus is either solitary or forms rosette colonies, which contrasts with the long ribbon-like chains observed in Eunotia in which frustules are bound at their valve surfaces or at their poles to form filamentous branched colonies (personal observation).

\section{Acknowledgements}

We would like to acknowledge the Coordination for the Improvement of Higher Education Personnel (CAPES) and the Federal University of Western Pará (UFOPA) for post-doctoral (PNPD) and scientific initiation fellowships to the first and second authors, respectively. We also thank anonymous reviewers for valuable suggestions.

\section{References}

ALENCAR, Y.B., LUDWIG, T.A.V., SOARES, C.C. and HAMADA, N. Stomach content analyses of Simulium perflavum Roubaud 1906 (Diptera: Simuliidae) larvae from streams in Central Amazônia, Brazil. Memorias do Instituto Oswaldo Cruz, 2001, 96(4), 561-576. http://dx.doi.org/10.1590/S007402762001000400020. PMid:11391432.

BICCA, A.B., TORGAN, L.C. and SANTOS, C.B. Eunotiaceae (Eunotiales, Bacillariophyta) em ambientes lacustres na Planície Costeira do Sul do Brasil. Revista Brasileira de Botanica. Brazilian Journal of Botany, 2011, 34(1), 1-19. http://dx.doi. org/10.1590/S0100-84042011000100002.

BRAUN, R. Limnologische Untersuchungen an einigen Seen im Amazonasgebiet. Schweizerische Zeitschrift Fur Hydrologie, 1952, 14(1), 1-128.

CANANI, L.G.C. and TORGAN, L.C. Two new Eunotia species with subapical costae, an uncommon structure for the genus. Diatom Research, 2013 , 28(4), 395-406. http://dx.doi.org/10.1080/02692 49X.2013.821425. 
DÍAZ-CASTRO, J.G., SOUZA-MOSIMANN, R.M., LAUDARES-SILVA, R. and FORSBERG, B.R. Composição da comunidade de diatomáceas periféricas do rio Jaú, Amazonas, Brasil. Acta Amazonica, 2003, 33(4), 583-606. http://dx.doi. org/10.1590/S0044-59672003000400005.

DUNK, B., RUWER, D.T. and FELISBERTO, S.A. Eunotiaceae Kützing (Bacillariophyceae) perifíticas de áreas úmidas do Cerrado (veredas) no Brasil. Iheringia. Série Botânica, 2016, 71(3), 283-295.

FERRARI, F., PROCOPIAK, L.K., ALENCAR, Y.B. and LUDWIG, T.A.V. Eunotiaceae (Bacillariophyceae) em igarapés da Amazônia Central, Manaus e Presidente Figueiredo, Brasil. Acta Amazonica, 2007, 37(1), 1-16. http://dx.doi.org/10.1590/S004459672007000100001 .

HUSTEDT, F. Neue und wenig bekannte Diatomeen. III. Phylogenetische Variationen Lei den rhaphidioiden Diatomeen. Berichte der Deutschen Botanischen Gesellschaft, 1952, 6, 133-144.

HUSTEDT, F. Neue und wenig bekannte Diatomeen. IX Susswasserdiatomeen aus Brasilien, inbesondere des Amazonasgebietes. Internationale Revue der Gesamten Hydrobiologie und Hydrographie, 1965, 50(3), 391409. http://dx.doi.org/10.1002/iroh.19650500305.

KOCIOLEK, J.P., LYON, D. and SPAULDING, S. Revision of the South American species of Actinella. In R. JAHN, J.P. KOCIOLEK, A. WITKOWSKI and P. COMPÈRE, eds. Studies on Diatoms. A.R.G. Koenigstein: Gantner Verlag K.G, 2001, pp. 131165.

KOCIOLEK, J.P., RHODE, K. and WILLIAMS, D.M. Taxonomy, ultrastructure and biogeography of the Actinella punctata species complex (Bacillariophyta: Eunotiaceae). Nova Hedwigia, 1997, 65, 177-193.

LIM, D.S.S., KWAN, C. and DOUGLAS, M.S.V. Periphytic diatoms assemblages from Bathurst Island, Nunavut, Canadian High Artic: an examination of community relationships and habitat preferences. Journal of Phycology, 2001, 37(3), 379-392. http://dx.doi.org/10.1046/j.15298817.2001.037003379.x.

MELO, S., REBELO, S.R.M., SOUZA, K.F., MENEZES, M. and TORGAN, L.C. Fitoplâncton. In: E.N. SANTOS-SILVA, F.M. APRILE, V.V. SCUDELLER and S. MELO, eds. Biotupé: meio fisico, diversidade biológica e sociocultural do Baixo Rio Negro, Amazônia Central. Manaus: Editora INPA, 2005, pp. 87-98.

MELO, S., SOPHIA, M.D.G., MENEZES, M. and SOUZA, C.A. Biodiversidade de algas planctônicas do Parque Nacional do Jaú: Janela Seringalzinho. In: S.H. BORGES, ed. Janelas para a Biodiversidade no Parque Nacional do Jaú: uma estratégia para o estudo da biodiversidade na Amazônia. Manaus: Fundação Vitoria Amazônica, 2004, pp. 83-90.
MELO, S., TORGAN, L.C. and RAUPP, S.V. Actinella species (Bacillariophyta) from an Amazon black water floodplain lake (Amazonas - Brazil). Acta Amazonica, 2010, 40(2), 269-274. http://dx.doi.org/10.1590/ S0044-59672010000200004.

METZELTIN, D. and LANGE-BERTALOT, $\mathrm{H}$. Tropical Diatoms of South America I. Iconographia Diatomologica, Königstein. Koeltz Scientific Books., 1998, 5, 695.

METZELTIN, D. and LANGE-BERTALOT, $\mathrm{H}$. Tropical Diatoms of South America II. Königstein: A.R.G. Verlag K.G., 2007, 877 p. Iconographia Diatomologica, vol. 18.

MONTOYA-MORENO, Y. and AGUIRRERAMIREZ, N. Knowledge to ecological preferences in a tropical epiphytic algae to use with eutrophication indicators. Journal of Environmental Protection, 2013, 4(11), 27-35. http://dx.doi.org/10.4236/ jep.2013.411A004.

PUTZ, R. Periphyton communities in Amazonian black- and whitewater habitats: Community structure, biomass and productivity. Aquatic Sciences, 1997, 59(1), 74-93. http://dx.doi.org/10.1007/ BF02522552.

RAUPP, S., TORGAN, L.C. and MELO, S. Planktonic diatom composition and abundance in the Amazonian floodplain Cutiuaú Lake are driven by the flood pulse. Acta Limnologica Brasiliensia, 2009, 21(2), 227-234.

RIMET, F. and BOUCHEZ, A. Life-forms, cell-sizes and ecological guilds of diatoms in European rivers. Knowledge and Management of Aquatic Ecosystems, 2012, 406(1), 1-14. http://dx.doi.org/10.1051/ $\mathrm{kmae} / 2012018$.

RIPPLE, H. and KOCIOLEK, J. The diatom (Bacillariophyceae) genus Actinella Lewis in Hawai' i. Pacific Science, 2013, 67(4), 609-621. http://dx.doi. org/10.2984/67.4.11.

ROUND, F.E., CRAWFORD, R.M. and MANN, D.G. The diatoms: biology and morphology of the genera. New York: Cambridge University Press, 1990, 747 p.

RUGGIERO, M.A., GORDON, D.P., ORRELL, T.M., BAILLY, N., BOURGOIN, T., BRUSCA, R.C., CAVALIER-SMITH, T., GUIRY, M.D. and KIRK, P.M. A higher level classification of all living organisms. PLoS One, 2015, 10(4), e0119248. http://dx.doi.org/10.1371/journal.pone.0119248. PMid:25923521.

SABBE, K., VANHOUTTE, K., LOWE, R.L., BERGEY, E.A., BIGGS, B.J.F., FRANCOEUR, S., HODGSON, D. and VYVERMAN, W. Six new Actinella (Bacillariophyta) species from Papua New Guinea, Australia and New Zealand: further evidence for widespread diatom endemism in the Australasian region. European Journal of Phycology, 2001, 36(4), 321-340. http://dx.doi.org/10.1080/0 9670260110001735478 . 
SIOLI, H. and SOARES, T. 50 anos de pesquisas em limnologia na Amazônia. Acta Amazonica, 2006, 36(3), 287-298. http://dx.doi.org/10.1590/S004459672006000300001 .

SIOLI, H. The Amazon and its main affluents: Hydrography, morphology of the river courses, and river types. In: H. SIOLI, ed. The Amazon. Limnology and landscape ecology of a might tropical river and its basin. Dordrecht: Dr. W. Junk Publishers, 1984, pp. 127-166. Monographiae Biologicae, 56.

SIVER, P.A., BISHOP, J., LOTT, A. and WOLFE, A.P. Heteropolar eunotioid diatoms (Bacillariophyceae) were common in the North American Arctic during the middle Eocene. Journal of Micropalaeontology, 2015, 34(2), 151-163. http://dx.doi.org/10.1144/ jmpaleo2014-005.

SOUZA-MOSIMANN, R.M., TAVARES, A.S. and FREITAS, V.P. Contribuição ao conhecimento da diatomoflórula do conteúdo estomacal de algumas espécies de peixes da Amazônia. I - Myleus sp. (Pacu) do lago do Prato, AM, Brasil. Acta Amazonica, 1997, 27(1), 9-26. http://dx.doi.org/10.1590/180943921997271026.

TREMARIN, P.I., KIM, K.I.M.B., MARRA, R.C. and LUDWIG, T.A.V. Additional data on morphology of Actinella leontopithecus-rosalia Costa (Bacillariophyta, Eunotiaceae). Phytotaxa, 2016, 247(4), 259-266. http://dx.doi.org/10.11646/phytotaxa.247.4.3.
UHERKOVICH, G. Algen aus einigen Gewässern Amazoniens. Amazoniana, 1981, 7(2), 191-219.

UHERKOVICH, G. and FRANKEN, M. Alfwuchsalgen aus zentralamazonischen Regenwaldbächen. Amazoniana, 1980, 7(1), 49-79.

UHERKOVICH, G. and RAI, H. Algen aus dem Rio Negro und seinen Nebenflüssen. Amazoniana, 1979, 6(4), 611-638.

UHERKOVICH, G. On the habitat, morphology and ultastructure of the pennate diatom Actinella mirabilis (Euler) Grunow. Archiv für Protistenkunde, 1986, 132, 363-376.

VAN HEURCK, H. 1881. Synopsis des Diatomées de Belgique. Atlas. Anvers: Édité par l'auteur. 1880-1881.

VON STOSCH, H.A. Methoden zur preparation keleiner oder zarter kieselelemente fur die elektronen und lichtmikroskopie, insbesondere von diatomeen und bei geringen materialmengen. Zeitschrift fur Wissenschaftlichen Mikroscopie, 1970, 70, 29-32.

WILLIAMS, D.M. and KOCIOLEK, J.P. Historical biogeography of Diatoms in Australasia: a preliminary assessment. In: M.C. EBACH, ed. Handbook of Australasian Biogeography. Boca Raton: CRC Press, 2016, pp. 17-46.

Received: 15 June 2017

Accepted: 20 July 2018 